\title{
A Monitoring and Control System for Stormwater Management of Urban Green Infrastructure
}

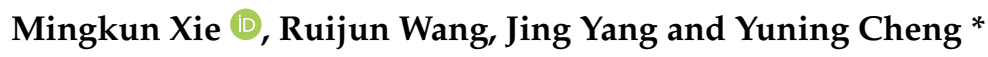

\begin{abstract}
Department of Landscape Architecture, School of Architecture, Southeast University, Nanjing 210096, China; mingkun.xie@seu.edu.cn (M.X.); ruijun1986@outlook.com (R.W.); 230159012@seu.edu.cn (J.Y.)

* Correspondence: 101004222@seu.edu.cn
\end{abstract}

check for updates

Citation: Xie, M.; Wang, R.; Yang, J.; Cheng, Y. A Monitoring and Control System for Stormwater Management of Urban Green Infrastructure. Water 2021, 13, 1438. https://doi.org/ 10.3390/w13111438

Academic Editors: Cristina M. Monteiro and Cristina Matos Silva

Received: 8 April 2021

Accepted: 18 May 2021

Published: 21 May 2021

Publisher's Note: MDPI stays neutral with regard to jurisdictional claims in published maps and institutional affiliations.

Copyright: (c) 2021 by the authors. Licensee MDPI, Basel, Switzerland. This article is an open access article distributed under the terms and conditions of the Creative Commons Attribution (CC BY) license (https:// creativecommons.org/licenses/by/ $4.0 /)$.
Abstract: Urban green infrastructure (UGI) can be used as a sustainable stormwater management approach. UGI can bring numerous ecological benefits to cities, including increased urban resilience, increased availability of water resources, and optimization of habitats. This paper used empirical research methods to describe an Internet of things (IoT)-based UGI monitoring and control system for stormwater management (MCSSWM). Using a Xuzhou-based practical project in China as a case study, we introduce the construction process, method, and monitoring results of the system. The results showed that the MCSSWM could be beneficial for UGI ecological performance evaluation and management.

Keywords: stormwater management performance; urban green infrastructure; real-time monitoring; intelligent control; Internet of things

\section{Introduction}

With the process of urbanization, the proportion of impermeable underwater surfaces is continuously increasing in cities, resulting in a series of urban stormwater problems, such as increasing surface runoff, waste of water resources, and water pollution [1]. In order to solve these problems, a series of stormwater management strategies and technologies have been implemented by some countries and organizations [2,3]. Among these strategies, green infrastructure (GI) is an innovative urban stormwater management approach widely used throughout the world with sustainable characteristics. Compared with urban gray infrastructure, urban GI (UGI) uses natural or simulated natural technology to promote a sustainable urban water cycle [4]. Moreover, the fundamental concept of UGI is closely related to the GI definition. The concept of GI dates back to the emergence of urban parks in the United States in 1850. According to the existing literature, UGI is defined as interconnected networks of natural and seminatural elements in the urban areas that provide multiple functions and ecosystem services, including positive ecological, economic, and social benefits for humans and other species [5,6].

A large number of studies have shown that the implementation of UGI can bring sustainable rainwater management benefits. However, the lack of effective evaluation methods for stormwater management performance makes it difficult to realize the efficient and full use of urban rainwater resources. Research by Roy et al. (2008) showed that 'one of the greatest barriers to the adoption of stormwater management techniques is a lack of data regarding their performance in various situations' [7].

Accurately collecting and evaluating ecological performance data obtained through the UGI represent the basis of quantitative research, which makes urban rainwater resource use more efficient. The development of the Internet of things (IoT) has provided a new technical tool for data acquisition [8,9]. In 1999, The MIT Auto-ID Laboratory pioneered the concept of IoT [10]. The IoT refers to the information network formed by combining various sensing devices with the internet. The purpose of IoT is to realize the connection and interaction between people and objects through the information network. Real-time 
monitoring of system performance and dynamic feedback are the two main applications in UGI performance research based on IoT technology [11].

This study introduces a monitoring and control system of stormwater management for performance evaluation and real-time management of UGIs. The objectives were as follows: (1) to introduce a monitoring and control system for stormwater management (MCSSWM) for UGIs using IoT technology to obtain real-time performance data and achieve a more accurate evaluation of UGIs, (2) to describe, in detail, the process, method, and content of MCSSWM system construction through a site-scale UGI case to provide a reference for the construction of related systems, and (3) to analyze stormwater management data obtained by the IoT in the last year of the UGI and verify the ecological benefits obtained by the project.

\section{Methods and Materials}

\subsection{The MCSSWM for UGIs}

The framework of MCSSWM includes three basic layers: hydrological data sensing, data management, and data application (Figure 1a). Arranging various hydrological sensors, we accessed the sensing of the basic hydrological data on the design site, such as rainfall, runoff, discharge, soil moisture of different soil layers, and the water level of the UGI. The data management layer mainly consisted of data transmission, storage, and management, including wireless transmitting nodes and cloud service platforms. The data application of MCSSWM mainly included four aspects: analysis of the runoff reduction effect, analysis of green water saving, analysis of site soil habitat improvement, and UGI real-time control [12-14]. A roadmap of MCSSWM for UGI application is shown in Figure $1 b$.

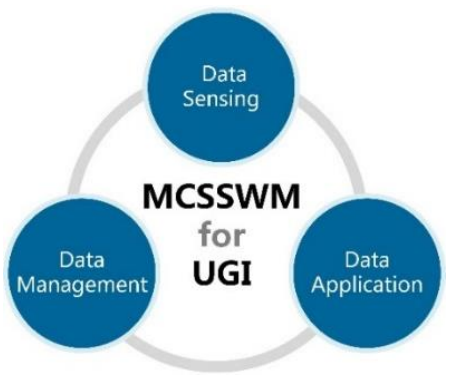

(a)

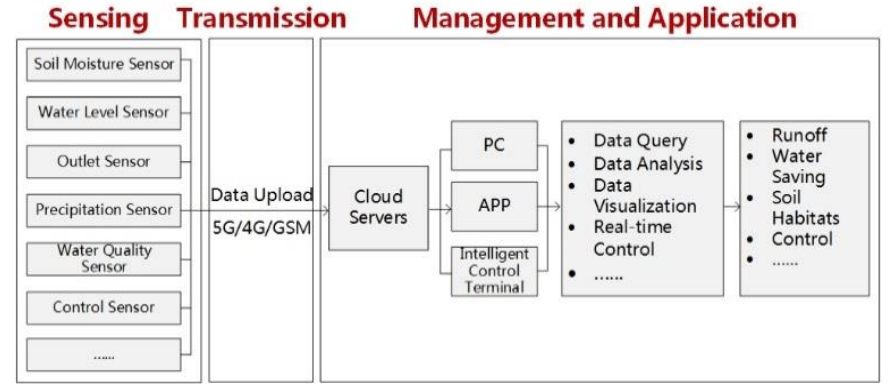

(b)

Figure 1. The framework of MCSSWM for UGI (a) and a roadmap of its application (b).

\subsection{Study Area}

Xuzhou is located in the southeast region of the North China Plain. Although located in the warm temperate climate zone, it has a serious shortage of water resources, which is also unevenly distributed in time and space. Xuzhou is one of the 40 cities in China most afflicted by a shortage of water resources [15]. Rainfall is mainly concentrated between June and September, with an average annual precipitation of $825 \mathrm{~mm}$, which is less than the annual average evaporation of $874 \mathrm{~mm}$. Therefore, seasonal shortages of water resources are frequent.

Our study site is located in the northwest area of Xuzhou city, with a total design area of $12,545 \mathrm{~m}^{2}$ (Figure 2a). The site's overall terrain is high in the north and east and low in the south and west (Figure 2b). The top layer of the underlying surface is mainly backfilled with surrounding construction waste and impervious granite, resulting in poor soil water-storage capacity (Figure 3). 


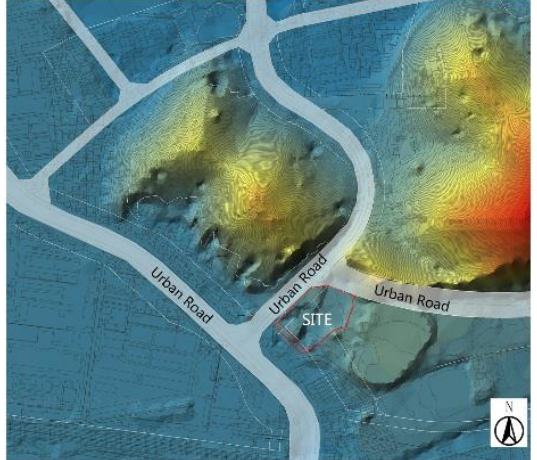

(a)

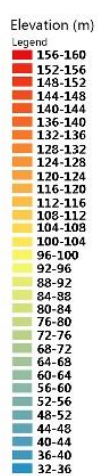

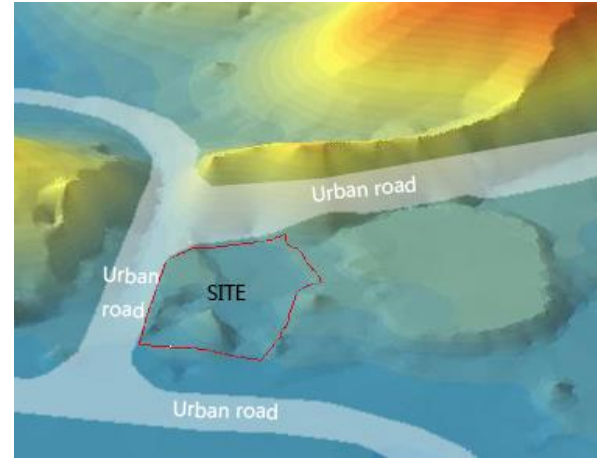

(b)

Figure 2. Digital elevation model of the study area: $2 \mathrm{D}$ view (a) and $3 \mathrm{D}$ view (b).

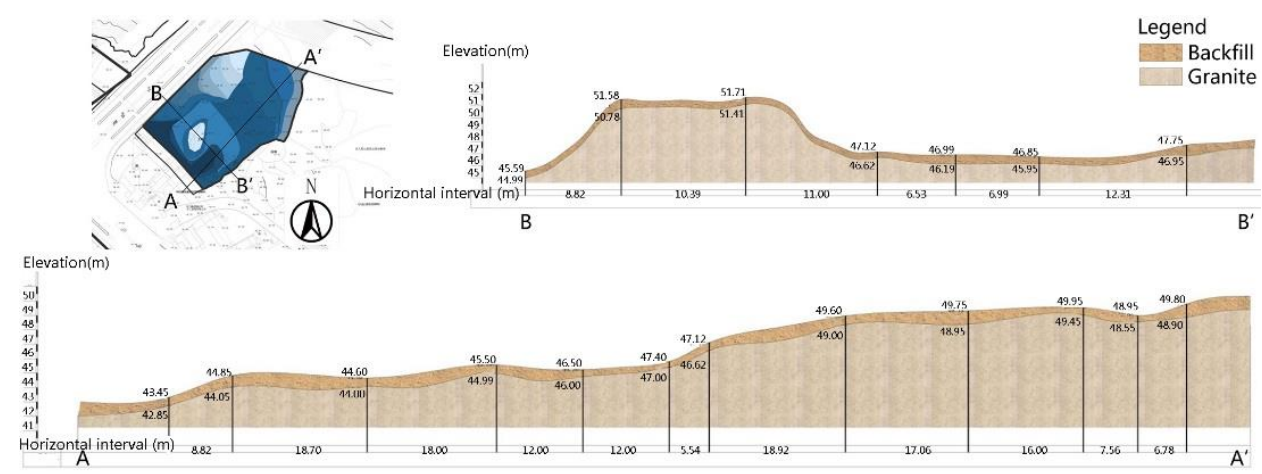

Figure 3. Soil profile of the study area.

Table 1 shows the basic information about the current state of the study area.

Table 1. Basic characteristics of the study area.

\begin{tabular}{|c|c|}
\hline Feature & Characteristic \\
\hline Climate & $\begin{array}{l}\text { The area belongs to a warm monsoon climate zone with } \\
\text { moderate rainfall. }\end{array}$ \\
\hline Rainfall & $\begin{array}{l}\text { The annual evaporation is greater than annual } \\
\text { precipitation, and rainfall is mainly concentrated from } \\
\text { June to September. }\end{array}$ \\
\hline Terrain & $\begin{array}{l}\text { The terrain is characterized as high in the north and low } \\
\text { in the south. }\end{array}$ \\
\hline Soil & $\begin{array}{c}\text { The soil is mainly composed of backfilled soil and } \\
\text { impervious granite, which has weak water } \\
\text { storage capacity. }\end{array}$ \\
\hline Surrounding situation & $\begin{array}{l}\text { An abandoned mining farm is located on the north side } \\
\text { of the site, with urban roads to the south and west, and a } \\
\text { landfill to the east. }\end{array}$ \\
\hline Vegetative cover & The vegetation coverage of the site is low. \\
\hline
\end{tabular}

\subsection{Construction of the MCSSWM}

2.3.1. Layout of the UGI

The design of a UGI integrates the landscape architecture, stormwater management, and ecosystem into a functional unit. According to the original site terrain, a UGI uses the height difference classification to store water. To use rainwater as efficiently as possible and to reduce evaporation, the UGI system slowly releases the collected stormwater through drip irrigation pipes. These pipes are used for fine irrigation of plant roots to enable 
independent irrigation. The layouts of the UGI and water storage facility structure on the site are shown in Figure 4.

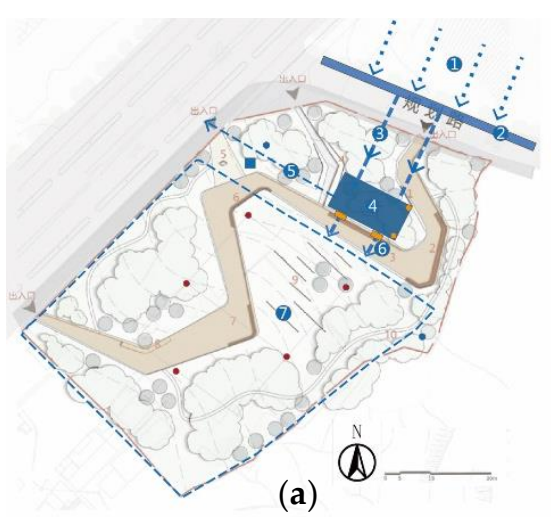

(a)

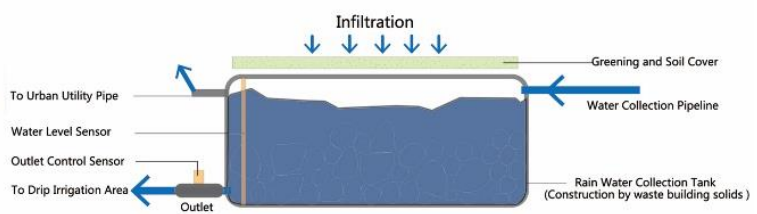

(b)

Legend

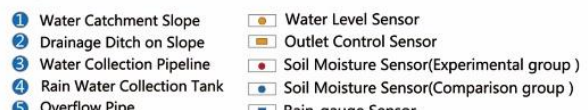
(6) Outlet Drip Irrigation Area

Figure 4. Layout of stormwater management facilities on site (a), and a schematic diagram of the water storage facility structure for harvesting and irrigation (b).

\subsubsection{Soil Moisture Sensors}

To compare the performance of the UGI design, a total of seven groups of soil moisture sensors (Smooth SMS-TS001, Nanjing, China.) were arranged at soil depths of 0.3, 0.7, 1.1 , and $1.5 \mathrm{~m}$ (considering the different rooting depths of vegetation) at various sites (Figure 5a). The rooting depths of 0.3 and $0.7 \mathrm{~m}$ were mainly chosen for ground cover and small shrubs, respectively, and arboreal rooting in the eastern China region mainly relates to the 1.1 and $1.5 \mathrm{~m}$ depths chosen. In the seven groups of sensors, five were arranged in the area of installed UGI facilities, and two were used for contrast in the area without such facilities. Other than the number of contrast group sensors, the settings were the same as those of the experimental group [16]. Moreover, the soil moisture sensors were connected to the electromagnetic valve of the storage water container. This connection enabled an automatic or manual determination of valve opening and closing states, as well as time, depending on soil moisture (Figure 5b) [17].

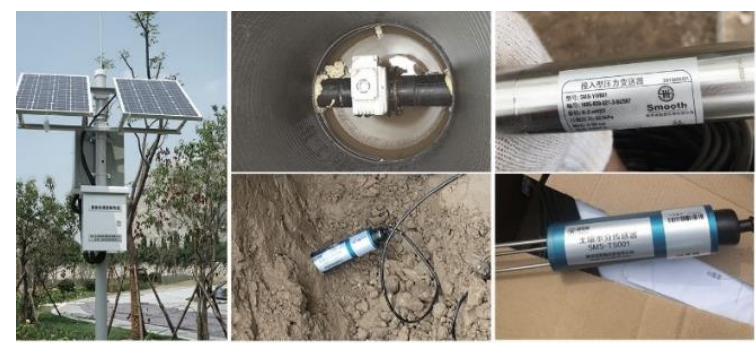

(a)

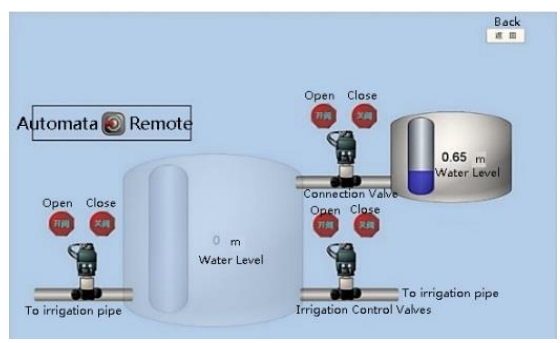

(b)

Figure 5. Pictures of sensor system setup (a), and terminal interface of water real-time intelligent control system $(\mathbf{b})$.

\subsubsection{Water-Level Sensors}

Considering that the site's water storage facility has a certain slope, water-level sensors were installed at the top and bottom of the water storage facility to accurately measure the water storage of stormwater. When the water level in the water storage area was lower than the horizontal plane at the bottom of the high-water-level meter, the low-water-level meter worked normally, but the high-water-level meter did not work. However, when the water level in the water storage area was higher than the maximum allowable water level, the measured value of the water-level meter at the lowest level reached the maximum and did not change, causing the high-water-level meter to work. The height of the water 
storage container was about $0.8 \mathrm{~m}$, and the water-level sensor had a testing range of $0-2 \mathrm{~m}$, which met the requirement for this study.

\subsubsection{Site Rainfall Sensor and Accessories}

The rain gauge sensor measured rainfall at the site and provided a reference for evaluating the effect of the UGI. The data collector was placed next to the rainfall and water-level sensors, and the soil moisture, rainfall, and water storage facility was connected using a wireless network. The data collector was placed in a waterproof chassis with a wind rod $2 \mathrm{~m}$ tall. The chassis was fixed, and solar panels, approximately $0.6-1.2 \mathrm{~m}$ long, were installed in order to use solar energy to power the system.

\subsubsection{Real-Time Water Control System}

The real-time control of water usage was mainly accomplished using data from the stormwater control-valve sensor. The equipment was installed the outlet of the water storage facility. The control-valve sensor adopted an automatic or manual mode to open or close as a function of the logical judgment from the cloud platform [18-20]. In automatic mode, the basis for opening or closing the irrigation system was the soil's available water content (AWC) [21] data obtained by the sensor arranged at different soil depths. When the soil moisture in the sensor at a depth of $1.1 \mathrm{~m}$ was less than $20 \%$, the sensor sent data through the network to the electric valve, and the electric valve automatically opened to irrigate the site's vegetation. In contrast, the valve was automatically closed when the soil moisture reached $30 \%$. The majority of the site irrigation targets had a root depth distribution range concentrated at around $1.1 \mathrm{~m}$. According to the site's soil properties, the soil's available water content ranged from $20 \%$ to $30 \%$, which is in line with moisture requirements for vegetation growth. This figure was used as the control-logic parameter to open or close the irrigation facilities [22]. In manual mode, the irrigation system can be remotely controlled through a mobile phone app or computer connected to the internet. In addition, the power supply can be provided by the field solar panels.

\section{Results and Discussion}

The stormwater performance monitoring data of the site were collected using the MCSSWM from 11 November 2016 to 11 September 2017. The site's stormwater management performance was analyzed and visually presented through the MCSSWM. The performance data indicated that the UGI effectively collected $988.5 \mathrm{~m}^{3}$ of stormwater at a harvesting rate of $75 \%$. The maximum harvesting of single-day rainfall occurred on 15 July 2017, with an amount of $152.4 \mathrm{~m}^{3}$ (Figure 6). The average soil moisture in the experimental groups at $0.3,0.7$, and $1.1 \mathrm{~m}$ was $10-25 \%$ higher than that of the area without the UGI. The biggest difference appeared at the depth of $1.1 \mathrm{~m}$ (Figure 7). This result suggests that the harvesting of site stormwater in water shortage areas was efficient. The UGI met the site irrigation requirements and optimized the site soil water environment.

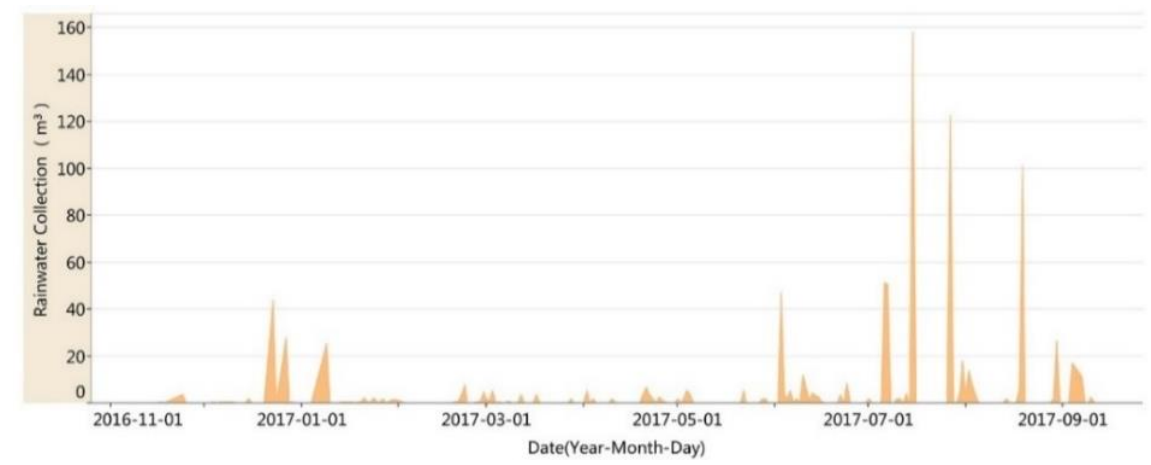

Figure 6. UGI daily rainwater harvesting statistics on site from November 2016 to October 2017. 


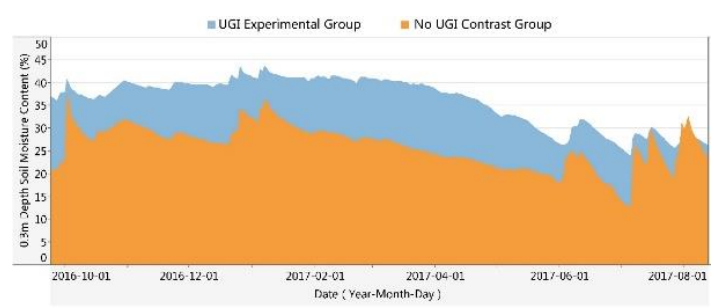

(a)

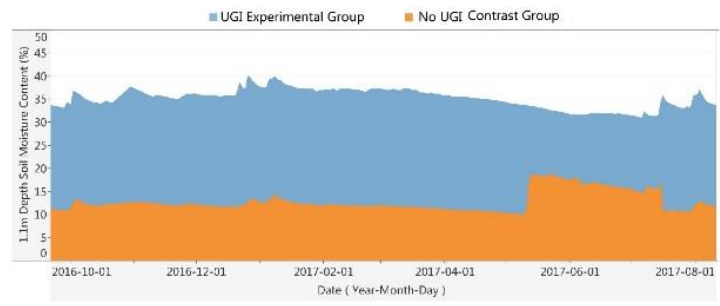

(c)

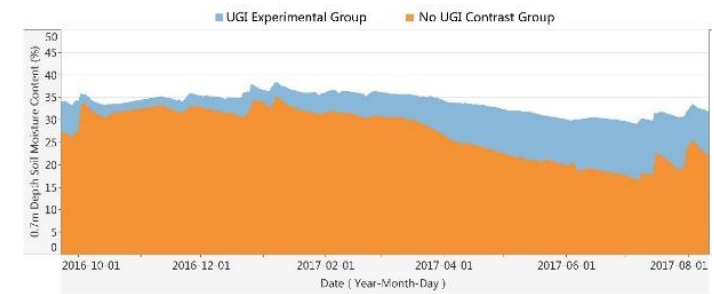

(b)

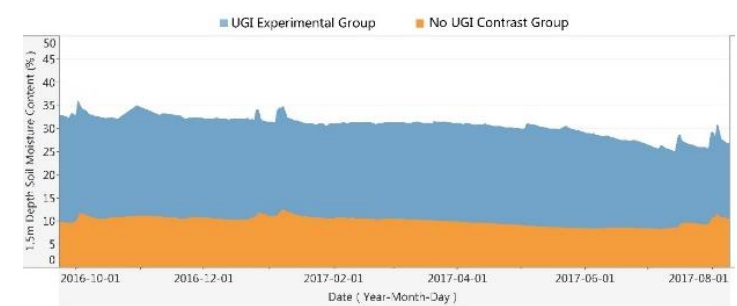

(d)

Figure 7. Comparison of soil moisture at depths of $0.3 \mathrm{~m}(\mathbf{a}), 0.7 \mathrm{~m}(\mathbf{b}), 1.1 \mathrm{~m}(\mathbf{c})$, and $1.5 \mathrm{~m}(\mathbf{d})$ between the UGI experimental group (blue) and the no UGI contrast group (orange) from October 2016 to August 2017.

Using the MCSSWM, the accurate hydrological time-series data of the study area from October 2016 to August 2017 were obtained. Specifically, the types of data included the amount of water collected by UGI and the soil moisture at different depths of the site with and without UGI. With the help of the hydrological time-series data, the amount of stormwater collected with UGI was clearly identified, the improvement of soil habitat with UGI was measured compared to that without UGI, and the achievement of the UGI's operation was evaluated. The relevant rainwater datasets can support meaningful conclusions regarding the claimed benefits of UGI.

The main purpose of the MCSSWM is to offer a valid tool for the performance evaluation of UGI. More importantly, by combining rainwater harvesting with the irrigation function of green space plants, urban water resources can be more sustainably and efficiently used. In many Chinese cities, the amount of water used for the irrigation of urban green space vegetation is huge due to the high proportion of urban green spaces and the richness of green space plant types. Especially for cities lacking water resources, the water used in urban green space is an important factor affecting the sustainable development of cities. The efficiency of harvesting and usage of rainwater is of great significance to alleviate the shortage of local water resources in arid and semiarid areas. Furthermore, many cities in eastern China are located in monsoon climate areas with relatively extensive rainfall in summer and less rainfall in autumn and winter. Therefore, the irrigation needs of the plant system can usually be met by high precipitation in summer, but water shortages may occur due to low precipitation in autumn and winter. Through the collection of rainwater and real-time control, the rainwater collected in summer can be used in the autumn and winter seasons to meet the cross-season demand of plant irrigation water.

Moreover, the effectiveness of MCSSWM was compared with similar rainwater management systems, namely, traditional green stormwater infrastructure (TGSI), rainwater harvesting agriculture (RHA) [23], stormwater control measures (SCMs) [24], and water quality monitoring system (WQM) [25]. It is found that MCSSWM significantly differed from other rainwater management systems in terms of application scopes, functions, and objectives of the system (Table 2). 
Table 2. Comparison of similar systems with MCSSWM.

\begin{tabular}{|c|c|c|c|c|}
\hline Systems & References & Functions & Objectives & Application Scopes \\
\hline $\begin{array}{c}\text { TGSI } \\
\text { (Traditional green } \\
\text { stormwater infrastructure) }\end{array}$ & $\begin{array}{l}\text { Benedict and McMahon } \\
\text { (2006) }\end{array}$ & $\begin{array}{l}\text { Conserve natural } \\
\text { ecosystem values } \\
\text { and functions. }\end{array}$ & $\begin{array}{l}\text { Provide a wide array of } \\
\text { benefits to people } \\
\text { and wildlife. }\end{array}$ & $\begin{array}{l}\text { For urbanized and } \\
\text { natural areas. }\end{array}$ \\
\hline $\begin{array}{c}\text { RHA } \\
\text { (Rainwater harvesting } \\
\text { agriculture) }\end{array}$ & Fengrui Li et al. (2000) & $\begin{array}{l}\text { Rainwater harvesting, } \\
\text { water-saving irrigation. }\end{array}$ & $\begin{array}{l}\text { Water management } \\
\text { in semiarid areas. }\end{array}$ & For agriculture areas. \\
\hline $\begin{array}{c}\text { SCMs } \\
\text { (Stormwater control } \\
\text { measures) }\end{array}$ & Laura Toran (2016) & $\begin{array}{l}\text { Increase infiltration, } \\
\text { reduce discharge } \\
\text { to streams. }\end{array}$ & Urban stormwater control. & For urbanized Areas. \\
\hline $\begin{array}{c}\text { WQM } \\
\text { (Water quality } \\
\text { monitoring system) }\end{array}$ & $\begin{array}{l}\text { LACDPW } \\
\text { (1998) }\end{array}$ & $\begin{array}{l}\text { Access to water quality } \\
\text { sampling data. }\end{array}$ & $\begin{array}{c}\text { Determine the total } \\
\text { pollutant emissions } \\
\text { and land-use-specific } \\
\text { discharges. }\end{array}$ & $\begin{array}{c}\text { For natural regions } \\
\text { by sampling stations. }\end{array}$ \\
\hline $\begin{array}{c}\text { MCSSWM } \\
\text { (Monitoring and control } \\
\text { system for } \\
\text { stormwater management) }\end{array}$ & - & $\begin{array}{l}\text { Monitor water volume } \\
\text { and real-time control. }\end{array}$ & $\begin{array}{l}\text { Performance evaluation, } \\
\text { intelligent control. }\end{array}$ & $\begin{array}{l}\text { For urban green } \\
\text { infrastructure. }\end{array}$ \\
\hline
\end{tabular}

However, the MCSSWM still has some limitations. Specifically, the current system design of MCSSWM is mainly applicable to site-scale GI stormwater management, but has limitations in large-scale application scenarios such as blocks and cities. Furthermore, during the operation of the MCSSWM in Xuzhou, some sensors were damaged during the construction process due to inappropriately buried sensors of the power supply line, resulting in data loss. Therefore, it is necessary to further optimize and upgrade the system in terms of hardware setup. In future system development and upgrades for MCSSWM, multiple categories of monitoring and management indicators can be integrated into the platform, such as air quality, soil conditions, and the role of UGIs in improving and optimizing the urban heat island effect.

\section{Conclusions}

This paper described a MCSSWM for the performance evaluation and real-time management of UGIs. Compared with traditional UGIs, the advantages offered by the MCSSWM for UGIs are obvious: (1) by obtaining accurate hydrological data, the performance evaluation of UGI stormwater management can be carried out accurately; (2) real-time control of UGI rainwater harvesting is possible; (3) accurate irrigation of site plants is possible by collecting rainwater to realize the flexible distribution of irrigation time and water quantity, especially in real-time control, to meet the cross-season demand of plant irrigation water.

With the intelligent and digital development of urban management, sensing systems are playing an ever-expanding role in the lives of urban residents. Big data, data mining, and other data management approaches, as well as application and analysis technology, will have a greater function in the future of cities. UGI is an important part of urban infrastructure, and the IoT can provide technical support for the acquisition of UGI data. Data-centered monitoring and real-time control systems represent the technical foundation to support the intelligent construction of UGIs, and they will become one of the future development directions for intelligent UGIs.

Author Contributions: Conceptualization, M.X. and Y.C.; methodology, M.X.; software, M.X.; validation, Y.C. and R.W.; formal analysis, R.W. and J.Y.; data curation, M.X.; writing-original draft preparation, M.X.; writing-review and editing, M.X.; visualization, M.X.; supervision, Y.C.; project administration, Y.C.; funding acquisition, Y.C. All authors have read and agreed to the published version of the manuscript.

Funding: This research was funded by the National Natural Science Foundation of China, grant number 51838003. 
Institutional Review Board Statement: Not applicable.

Informed Consent Statement: Not applicable.

Data Availability Statement: The data presented in this study are available on request from the corresponding author.

Acknowledgments: We would like to acknowledge Meixin Zhao and his team for their assistance in installing and debugging the monitoring and control devices.

Conflicts of Interest: The authors declare no conflict of interest.

\section{References}

1. Berndtsson, J.C. Green roof performance towards management of runoff water quantity and quality: A review. Ecol. Eng. 2010, 36, 351-360. [CrossRef]

2. Wong, H.F. Water sensitive urban design-The journey thus far. Aust. J. Water Resour. 2015, 10, 213-222. [CrossRef]

3. Jia, H.F.; Yao, S. Advances in lid bmps research and practice for urban runoff control in china. Front. Environ. Sci. Eng. 2013, 7, 709-720. [CrossRef]

4. Ahiablame, L.M.; Engel, B.A.; Chaubey, I. Effectiveness of low impact development practices: Literature review and suggestions for future research. Water Air Soil Pollut. 2012, 223, 4253-4273. [CrossRef]

5. Li, C.; Peng, C.; Chiang, P.; Cai, Y.; Wang, X.; Yang, Z. Mechanisms and applications of green infrastructure practices for stormwater control: A review. J. Hydrol. 2019, 568, 626-637. [CrossRef]

6. Robert, Y.; Julie, Z.; Katherine, L. A comprehensive typology for mainstreaming urban green infrastructure. J. Hydrol. 2014, 519, 2571-2583.

7. Roy, A.H.; Wenger, S.J.; Fletcher, T.D.; Walsh, C.J.; Ladson, A.R. Impediments and solutions to sustainable, watershed-scale urban stormwater management: Lessons from australia and the united states. Environ. Manag. 2008, 42, 344-359. [CrossRef] [PubMed]

8. Batty, M.; Axhausen, K.W.; Giannotti, F. Smart cities of the future. Eur. Phys. J. 2012, 214, 481-518. [CrossRef]

9. Carlo, R.; Dennis, F.; Riccardo, M.P.; Sarah, W. Mobile landscapes: Using location data from cell phones for urban analysis. Environ. Plan. B 2006, 33, 727-748.

10. Mit Auto-Id Laboratory. Available online: https:/ / autoid.mit.edu/ (accessed on 15 January 2020).

11. Meng, T.; Hsu, D.; Wadzuk, B. Green Stormwater Infrastructure Use and Perception on Related Smart Services: The Case of Pennsylvania. In Proceedings of the World Environmental and Water Resources Congress, West Palm Beach, FL, USA, 22-26 May 2016; Pathak, C.S., Reinhart, D., Eds.; ASCE (American Society of Civil Engineers): New York, NY, USA, 2016.

12. Sensor Terminology. Available online: https://www.ni.com/zh-cn/innovations/white-papers/13/sensor-terminology.html (accessed on 15 January 2020).

13. Wen, L.; Weiping, C.; Chi, P. Assessing the effectiveness of green infrastructures on urban flooding reduction: A community scale study. Ecol. Modell. 2014, 291, 6-14.

14. Jayasooriya, V.M.; Ng, A.W.M. Tools for Modeling of Stormwater Management and Economics of Green Infrastructure Practices: A Review. Water Air Soil Pollut. 2014, 225, 2055. [CrossRef]

15. Zu, Z.H.; Wang, K.L.; Song, G.C. Full utilization of rainfall runoff as an effective way for development of water resources in arid and semi-arid regions of China. In Proceedings of the 8th International Conference on Rainwater Catchment Systems, Tehran, Iran, 25-29 April 1997; Aminipouri, B., Ghoddousi, J., Eds.; IRCSA/Min of Jihad-e-Sazandegi: Tehran, Iran, 1997.

16. Soulis, K.X.; Elmaloglou, S. Optimum soil water content sensors placement for surface drip irrigation scheduling in layered soils. Comput. Electron. Agric. 2018, 152, 1-8. [CrossRef]

17. Divani, D.; Patil, P.; Punjabi, S.K. Automated Plant Watering System. In Proceedings of the 5th IEEE International Conference on Computation of Power, Energy, Information and Communication (ICCPEIC), Melmaruvathur, India, 20-21 April 2016; IEEE: New York, NY, USA, 2016.

18. Vellidis, G.; Tucker, M.; Perry, C.; Wen, C.; Bednarz, C. A real-time wireless smart sensor array for scheduling irrigation. Comput. Electron. Agric. 2008, 61, 44-50. [CrossRef]

19. Simbeye, D.S.; Zhao, J.M.; Yang, S.F. Design and deployment of wireless sensor networks for aquaculture monitoring and control based on virtual instruments. Comput. Electron. Agric. 2014, 109, 31-42. [CrossRef]

20. Han, H.G.; Zhu, S.G.; Qiao, J.F.; Guo, M. Data-driven intelligent monitoring system for key variables in wastewater treatment process. Chin. J. Chem. Eng. 2018, 26, 2093-2101. [CrossRef]

21. Available Water Capacity. Available online: www.environment.nsw.gov.au/resources/soils/testmethods/awc.pdf (accessed on 15 January 2020).

22. Thompson, R.B.; Gallardo, M.; Valdez, L.C.; Fernandez, M.D. Using plant water status to define threshold values for irrigation management of vegetable crops using soil moisture sensors. Agric. Water Manag. 2007, 88, 147-158. [CrossRef]

23. Cook, S.; Burch, J.; William, R.; Geballe, G.T. Rainwater harvesting agriculture: An integrated system for water management on rainfed land in china's semiarid areas. AMBIO 2000, 29, 477-483.

24. Laura, T. Water level loggers as a low-cost tool for monitoring of stormwater control measures. Water 2016, 8, 346.

25. Lee, H.; Stenstrom, M.K. Utility of Stormwater Monitoring. Water Environ. Res. 2005, 77, 219-228. [CrossRef] [PubMed] 